\title{
磁気双極子場のオンオフ符号による存在検出系と その野生小動物行動記録への応用
}

\author{
鈴 木 岳 良*金 子 弥 生**.阿刀田 央 一* \\ 丸 山直 樹**.冨 澤 眞 樹***. 神 崎 伸 夫**
}

Existence Detection by On-off Code of Magnetic Dipole Field and

Its Use in Recording Small Wild Animal's Behavior

Takeyoshi SuzUKi*, Yayoi KANEKo**, Oichi ATODA*, Naoki MARUYAMA**, Masaki TOMISAWA ${ }^{* * *}$ and Nobuo KANZAKI**

\begin{abstract}
A simple but reliable method is proposed for detecting existence of an object within a circular area with about $4 \mathrm{~m}$ radius, which is optimal for logging trace of small wild animals. A beacon equipped with a magnetic dipole whose field is turned on and off according to its specific serial code is placed somewhere on the ground. If a magnetic sensor carried by an animal detects the field and find that the serial bit-pattern matches to one of predetermined codes, existence of the animal within the area around the corresponding beacon is known. It is shown theoretically that the radius of detectable area is very stable against changes of sensor height, sensor inclination, and other electronic parameters since strength of dipole field is inversely proportional to cubed distance. A 14-bit code set including 622 individual codes are devised so as to decrease theoretical probability of spurious detection by introduction of Hamming distance and exclusion of bit-patterns with very little 1s. Chance of erroneous response to impulse and burst noise is also minimized. A trace-recording system is developed. In practical system the dipole coil is driven by $\mathrm{AC}$ in audio frequency band. A very low-power recording unit including a tiny sensing coil, an AGC amplifier, an analog comparator, a real-time clock, a static RAM, a micro CPU and lithium batteries is developed. The system is applied to research on a male badger. 65 beacons are deposited. During 40 days in late spring, 521 successive errorless records are acquired. Ecological analysis extracted five patterns of its nightly activities and revealed that it trips around its home range in every 3 to 4 days. Thus existence detection by coded magnetic field offers an effective instrument to animal ecologists.
\end{abstract}

Key Words: existence detection, magnetic sensing, telemetry

\section{1. まえがき}

動物生態学の分野では, 動物個体間の接触や環境との相互 作用を知るため, 生息分布などのマクロな情報以外に，個体 の行動を詳細に追跡する要求が生じている，現在，同分野で

† 1997 年電子情報通信学会総合大会で発表 $(1997 \cdot 3)$

* 東京農工大学大学院生物システム応用科学研究科 小金井市 中町 $2-24-26$

**. 東京農工大学農学部 府中市幸町 3-5-8

*** 前橋工科大学工学部 前橋市上佐鳥町 460-1

* Graduate School of Bio-Applications and Systems Engineering (BASE), Tokyo University of Agriculture and Technology, Koganei

** Faculty of Agriculture, Tokyo University of Agriculture and Technology, Fuchu

*** Faculty of Engineering, Maebashi Institute of Technology, Maebashi

(Received January 30, 1998)

(Revised October 14, 1998)
事実上唯一の観測手段である電波テレメトリ ${ }^{1), 2)}$ で空間分解 能を上げるには，発信源に近接し，かつ基線長を大きくする ことが必要で, 研究者が指向性アンテナを持って山野を走り 回らなければならない. 当然時間的な観測密度は低く, 詳細 な行動追跡は無理である。また複数個体の同時観測は困難で ある. 計測工学分野から, 複数個体の高い空間分解能のデー 夕を, 高い時間密度で自動収集する手法が供給されれば, 研 究のブレークスルーが期待できる。本論文では, 夕ヌキやア ナグマなどの小動物に適する新たな観測手法を提案する.

一般に広い地域内での位置を知る場合, GPS や電波テレ メトリのように，座標を直接求める方法と，位置が既知の標 識を道しるべとし，その近傍に観測対象が存在することを知 る, 存在検出系による方法が考えられる. 物理媒体としては, 波動場と双極子場が考えられる。前者はパワーが距離の逆 2 乗則に従う. 波長によって回折の大きさが変わるので, みか け上の性質が大きく異なる，後者の強さは, 逆 3 乗則に従 
う。また地上に固定される観測起点と移動する観測対象の, どちらを場の生成側とするかによって系の構成が変わる．標 識や観測対象の識別法にもいくつかの選択肢がある。また実 用的な見地から, 消費電力やサイズなども検討する必要があ る. 一口に位置を知る系といっても, これらの中から, 目的 にもっともよく整合する組み合わせを選択する必要がある. たとえばテキサスインスツルメンツ社のタイリス ${ }^{3)}$ のうに, 固定側の場が供給する電力で信号場を発生する超小型トラン スポンダの存在を, 固定側が $1 \mathrm{~m}$ 程度の範囲内で検出すると いう選択は, 家畜の体内に埋め込んで狭い通路や搾乳機など で個体識別を行う目的には最適であるが, 最も強い信号が一 つだけ検出されるので, 同時観測には適さない.

タヌキやアナグマなどの野生小動物の動物生態学的観測の 場合, 観測する土地の広さは $0.1 \sim 1 \mathrm{~km}^{2}$ 程度である. 動物生 態学の研究では, 動物が, 餌場, 巣穴, フン場, 人間環境と 接触する場所などの, 行動圈内 ${ }^{4)}$ および周辺の, 100 個程度 の意味のある場所に来たことが重要な情報となる. 観測対象 個体の行動圏の範囲や餌場の候補などは事前調査されている. 旉いておいた紙の足跡によって検知する方法もある. 家族行 動や接触による病気感染の研究では, 複数個体の同時観測も 必要である. 動物に取り付けられる重量は体重の $5 \%$ 以下で あり, GPS が適用できそうなのはシカ程度以上である ${ }^{5)}$. 小

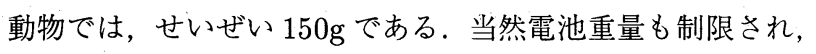
例えば数 $10 \mathrm{~g}$ の電池で 3 ケ月程度動作させる.

以上より, 小動物の行動追跡の目的には, 複雑な高分解の 測量系を用いるよりも, 必要な場所に標識を設置し, それら の半径 3 4m の近傍で観測対象個体の存在を検出し, その 標識の識別子, 時刻とともに報告する系を提供すればよい. 動物側を識別符号の送信側とする場合, 周波数分割や時分割, イーサネットでの衝突検出／再試行のような, 符号の分離法 が何か必要である. 一方, 複数の受信側は相互干渉しないの で, 標識側で識別符号付きの場を生成し, 動物個体側に場を 検出するセンサ系を取り付けるべきである，通常巣穴や飭場 は空間的に分離し, 場の混信の危険はない. 要する電力の点 からも，場の生成は固定側におくのが適当である.

長波長の波動は, 個体が飭場や巣穴などの特定の場所に来 たことを知るだけの分解能を期待できない. 光などの短波長 の波動は樹木などに隠蔽され，また巣穴に入られたらまった く観測不能になる. GPS はこの点でも使用不可である. 音場 は観測対象に知覚される盧がある. 結局, 磁気双極子場の強 さの距離依存性によって分解能を得るのが適当と考える. 識 別子の変調法は, 標識を山野に多数設置するため, 確実で安 価な方法としたい. 古典的な無線電信以来最も確実な方法は キャリア自体の断続で, 送受信とも極めて安価な回路で済む.

以上により, 本論文の存在検出系の構想が成立する. 本論 文では, この形式の存在検出系について, 場と符号集合の性 質の理論的検討を行う.また実用的な存在検出系，およびこ れを組み込んだ野生小動物の行動記録システムを示す。とく に低電力設計は, 理論的な問題ではないが, アイデアやト
レードオフ設計が実用的なシステムの成否の鍵となるので詳 述する。また夕ヌキおよびアナグマを対象に, 動物生態学の 研究に使用して得た結果の例を示す。

\section{2. 場と符号の理論的検討}

存在検出，すなわちセンサが特定の標識の近傍に存在する ことを知る原理はきわめて簡単で，存在を知りたい場所それ ぞれに，固有のシリアル符号によってオンオフ変調された双 極子磁場を発生する標識をおく．この磁場を磁気センサで検 出し，検出した值が䦨值を超えたとき論理レベルを 1 ，そう でなければ 0 とする．時系列上のビットパターンが予め定め られた符号集合の中の一つに一致したとき，センサ自身が符 号に対応する標識の近傍に存在することが検出される．符号 集合の中のどれにも一致しなければ棄却し，存在は検出され ない. センサの存在が検出される領域を, 検出域とよぶ.

一般的に次のような性質が, 存在検出系として望ましい.

（1）検出域の境界がはっきりしている．標識からある一 定の距離以内にセンサがあれば存在が確実に検出され，そ の距離以遠では存在が検出されることはない.

（2）センサの高さ，姿勢，センサ系のパラメー夕変動な どによって, 検出域の大きさが変動しにくい.

(3) 他の標識の符号と誤認されることがない.

上記の方法による存在検出系がこの性質を満たすかどうか を調べるため，場の形状および符号系について検討する．

[場の性質］ここでは磁気双極子場を存在検出に利用し た場合の特性, とくに各種の変動要因の影響について調べる. 原点にあり， $z$ 軸上に軸をもつ双極子による場は，古典電磁 気学にて周知のごとく, $z$ 軸に対して円対称で, 各点におけ る $z$ 軸に平行な成分, 半径方向の成分の大きさは,

$$
\left(r^{2}-2 z^{2}\right) /\left(r^{2}+z^{2}\right)^{5 / 2}, \quad 3 r z /\left(r^{2}+z^{2}\right)^{5 / 2}
$$

大きさの絶対値は

$$
\left(r^{2}+4 z^{2}\right)^{1 / 2} /\left(r^{2}+z^{2}\right)^{2}
$$

に比例する．ただし $r=\left(x^{2}+y^{2}\right)^{1 / 2}$ とする。これらはすべ て原点からの距離の-3 乗に比例する. $z=0$ なら, 磁場の 強さはただちに $r^{-3}$ に比例する．実際のコイルによる磁場 は上式に非常によく合致し, 磁気式モーションキャプチャ装

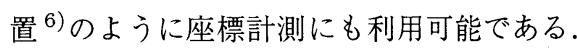

検出域を地表面上の円形領域としたいので，磁気双極子の $z$ 軸をほほ鉛直にしてこの検出域の中央におき, 円対称性を 確保する．すなわち上式中 $r$ は地表面への射影半径, $z$ は標 識の中心とセンサの高さの差となる。実際の $z$ の大さは， 高々検出域半径の 10 分の 1 である。この磁場が閾値を超え たことを，軸をほほ鉛直にした磁気センサで検出する．

Fig.1(a) には, $\left(r^{2}-2 z^{2}\right) /\left(r^{2}+z^{2}\right)^{5 / 2}=r_{0}^{-3}$ となる $r / r_{0}$ の值を, $z / r_{0}$ に対して示す.これはセンサを鉛直に保っ たまま高さを変えたときの検出域の半径の相対的な変化を表 す.これによると，半径の $10 \%$ おび $20 \%$ の高さのところ 
(a)

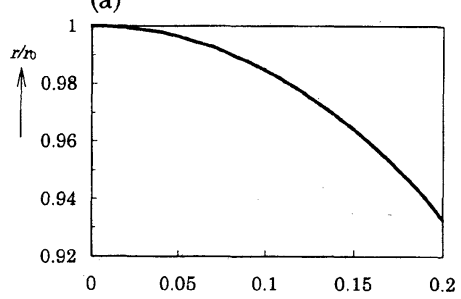

(b)

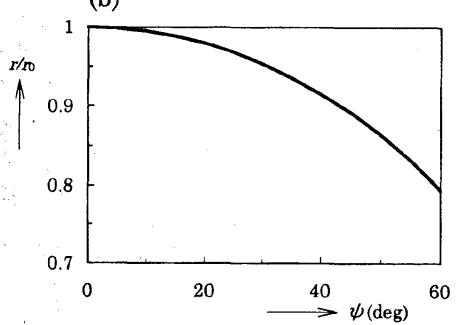

Fig. 1 (a) $r / r_{0}$ vs. $z / r_{0}$ such that $\left(r^{2}-2 z^{2}\right) /\left(r^{2}+z^{2}\right)^{5 / 2}=$ $r_{0}^{-3}$ showing change of the radius of detectable area when sensor is lifted by $z$. (b) $r / r_{0}$ vs. $\Psi$ such that $r^{-3} \cos \Psi=r_{0}^{-3}$ showing the fluctuation of the radius of detectable area caused by angular swing of the sensor.

では，検出域の半径は高さ 0 の位置に比べてそれぞれ $1.5 \%$, $7 \%$ 減少する。一方 $\left(r^{2}+4 z^{2}\right)^{1 / 2} /\left(r^{2}+z^{2}\right)^{2}=r_{0}^{-3}$ となる $r / r_{0}$ の值の $z / r_{0}$ による変化は，センサの姿勢変動を許した 場合の, 各高さでの検出域の最大半径を表す。この場合では, 高さ $20 \%$ に対する変化はー $0.14 \%$ ある。一方，七ン州亳

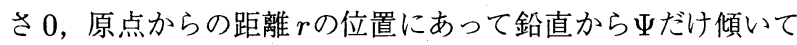
いるとすれば, 出力は $r^{-3} \cos \Psi$ に比例するから，これを $r_{0}^{-3}$

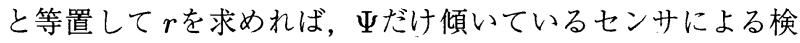
出域の半径を与える。 この相対值, $r / r_{0}=(\cos \Psi)^{1 / 3}$ を $\Psi$ に 対して Fig. 1(b)に示す.

Fig. 1(a), (b)の $r / r_{0}=1$ からの偏差は, 微小として加法 的に扱う。たとえば $|z|$ の最大值が $0.1 r ，|\Psi|$ の最大值が $30^{\circ}$ としたときの検出域の半径の変化は，最大一 $6.5 \%$ ある。．ま た何らかの原因でセンサ系のゲインが相対的にとだけ変化し たとすると，検出域の相対変化は $r^{-3}(1+\varepsilon)=r_{0}^{-3}$, すなわ $ち r / r_{0}=(1+\varepsilon)^{1 / 3} \simeq(1+\varepsilon / 3)$ である.

すなわち技術的なレベルでの誤差要因，例えば磁場発生コ イルの駆動電圧の変動やセンサ感度のばらつきなどによるゲ イン変動が検出域に与える相対変化は, 線形近似範囲ではゲ インの相対的変動の $1 / 3$ に圧縮される。また変動が大きい場

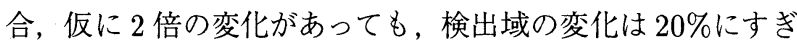
ない，以上のように，存在検出に磁気双極子場を利用するこ とは，双極子場の逆 3 乗則により，センサ姿勢などの外部要 因, センサ感度などの内部要因の変動ともに, 検出域の変動 に与える影響が小さいという利点が得られる。

[符号集合］前述のように符号は，場のオンオフによる シリアル 2 值符号として伝達される。ノイズが存在する場合, 標識からある距離 $r_{0}$ を境に急に符号の全ビットが 0 になるわ (a)
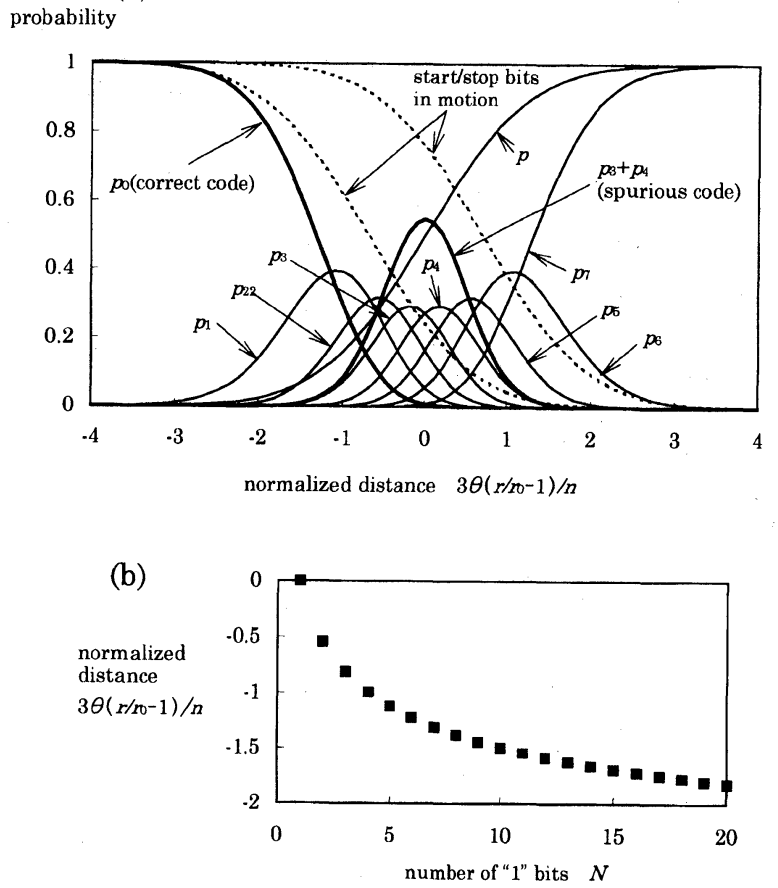

Fig. 2 (a)Probability $p$ of missing respective bits, $p_{0}$ for correct code detection, and $p_{k}$ for missing $k$ bits of logical 1 for $N=7$, versus normalized distance from the beacon. $p_{3}+p_{4}$ represents probability of spurious detection for codes with more than two 1s. (b)Change of the radius of detectable area according to $N$ evaluated by $p_{0}=1 / 2$.

けではない。この検出域の境界付近で符号を得るときの確率 のモデルと，符号集合がもつべき性質を論ずる必要がある。

比較器, すなわち論理レベルの 1,0 を閾值 $\theta$ よって 判定する部分への入力は, 磁場強度に比例する部分 $s$ と 不規則ノイズの和とする。磁場強度の距離による変化 は, 前述の逆 3 乗則による $s=\theta\left(r / r_{0}\right)^{-3}$ を検出限界 $r_{0}$ 付近で線形化し, $\left(r / r_{0}\right)^{-3}=\left(\left(r_{0}+r-r_{0}\right) / r_{0}\right)^{-3}=$ $\left(1+\left(r-r_{0}\right) / r_{0}\right)^{-3} \simeq\left(1-3\left(r-r_{0}\right) / r_{0}\right)=\left(1-3\left(r / r_{0}-1\right)\right)$ より, $s=\theta\left(1-3\left(r / r_{0}-1\right)\right)$ とする。ノイズの振幅密度分 布は平均值 0 , 分散 $n^{2}$ のガウス分布で, $n$ は $\theta$ の数分の 1 以 下の範囲で考える，この仮定に従えば，本来論理レベル 1 で あるビットが 0 と判定される確率は $p$ は,

$$
p=\int_{-\infty}^{3 \theta\left(r / r_{0}-1\right) / n} \frac{1}{\sqrt{2 \pi}} \exp \left(-\frac{u^{2}}{2}\right) d u
$$

のように書ける。 0 が 1 と判断される確率は無視できる.

一方 $N$ ビットの 1 をも符号のうち $k$ ビットが 0 と判断さ れる確率は，ノイズが各ビット独立であるとすれば， $(N, k)$ を 2 項係数として,$p_{k}=(N, k) p_{k}(1-p)^{(N-k)}$ で与えられ る。例えば $N=7$ として, $p$ および $p_{k}$ を $3 \theta\left(r / r_{0}-1\right) / n$ に 対してプロットすれば, Fig. 2(a)のようになる.

符号が正常に得られる確率 $p_{0}$ がある $r$ の值を境に 1 から 0 にステップ状に近い急峻な変化をし，また符号が他の標識 
のものと誤認される確率が小さいことが望ましい. Fig. 2(a) によれば, $p_{0}=(1-p)^{N}$ はすでに $1-p$ よりすこし急峻に なっていて，そのまま利用できよう。一方後者に対しては， 1) 符号を他の標識のものと誤認する可能性のあるrの範囲を 極力小さくし，その範囲への検出対象の滞在確率を下げるこ と，および 2) 上記範囲内では，誤認する確率自体を小さく すること，の両面から符号集合を考える。

まず 1)については, $k$ が 0 および $N に$ 近い側での広がりが 大きいため，符号間のハミング距離を離す，ビット数が極め て少ない符号は使用しない，という戦略が有効である。た えば Fig. 2(a)の例では，ハミング距離 3 の符号系を使用し， かつ 1 が 2 ビット以下の符号が存在しないとすれば, $p_{1}, p_{2}$, $p_{5}, p_{6}$ は符号誤認確率に寄与しない. また 2$)$ は, 符号密度 $\rho$ を下げるしかないが，これは符号間にハミング距離をおくこ とと両立する. Fig. 2(a) に示す $\left(p_{3}+p_{4}\right)$ を $\rho$ 倍したものが， 符号誤認確率である。第 4 章に示した $n / \theta$ の実際的な数值は,

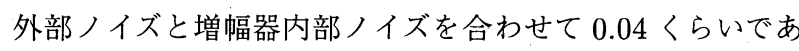
る。また符号密度は, 第 3 章の例では $\rho=0.04$ 程度である.

Fig. 2(b) には, $p_{0}$ が $1 / 2$ になる $3 \theta\left(r / r_{0}-1\right) / n$ の值を $N$ に対して示したものである。これによれば，実用的な $N$ 範 囲内で検出域半径は最大 $1.9 n / 3 \theta<ら い$ 後退する. $n / \theta$ とし て上記の数値を用いれば，この值は約 $2.5 \%$ あるる.

上記のモデルでは，まだ次の二点が考慮されていない．

（1）実際のシリアル符号系では必ず，符号の前後に必ず スタートビット, ストップビットがつく．この 2 ビットが 1 でなければ, 符号として認めない.

（2）実際の対象は，ほとんどの場合移動している.

スタートビット，ストップビットは時間的に両端にあり，移 動の影響を最も強く受けるので, 上記 (1)（2）を同時に考慮 する，これらのビットも符号ビットと変わらないので，セン サが静止していれば，正しく得られる確率はそれぞれ $1-p$ に等しい，移動の向きが一定とすれば，時刻の違いによる位 置のずれにより，二者の受信確率は $1-p$ を横軸上にそれぞ れ逆方向にずらしたのと等価で, Fig. 2(a) 中に2 本の破線で 概念的に示したようになる。結果として，正常検出確率およ び誤認確率は，それぞれ $p_{0}$ と $\rho\left(p_{3}+p_{4}\right)$ に破線の 2 つの值の 積を乗じたものとなる．これらの值は移動速度とビットレー トの比によって定まるが, 正常検出確率はあまり変わらない のに対し，誤認確率をかなり小さくする方向にはたらく．

以上より，検出域境界をセンサが通過するとき，符号の誤 認は事実上ないといってよい程度まで確率を下げることがで きる，これと，条件変化に対して感度の小さい双極子場の性 質を併せれば，安定した確実な検出域が得られる。

\section{3. 実際の符号}

筆者らは各ビット $4 \mathrm{~ms}, 16$ ビットのシリアル符号を用いた. 符号の全長は $64 \mathrm{~ms}$ である。両端の 1 ビットをスタート，ス トップビット，実質部を 14 ビットとし，調歩同期によって各 ビットを捕捉する．符号のデューティ比は $1 / 4$ とし， $256 \mathrm{~ms}$
に 1 回毎とした. 4 回/s の符号レートは, 小動物用の応用目 的に対して十分高速である。

実際の磁気雑音は，ガウス性不規則雑音とは異なるものも 多い. 実験室環境でよく観測されるノイズは, 散発的なパル スで，ときとして論理レベル 1 とみなされる．原因ははっき りしないが, 器具のオンオフに伴うステップ状の電流変化が, 屋内配線周囲の磁場変化として広く放射されるのではないか. 商用周波数に同期したパルス列が 0.1 秒くらい現れることも ある. TV 受像器から $3 \mathrm{~m}$ 程度以内では 1 が検出されたまま になる，センサの機械的衝撃による音響振動もノイズを発生 し，これも連続した 1 である。鉄道線路は，架線と線路の間 の電流ループによる巨大な磁気雑音源である．幹線の線路に $20 \mathrm{~m}$ 以内に接近すると，連続する 1 に時々 0 が介在したり， 電車の位置によっては似かよったビットパターンが繰り返し たり，複雑であるが総じて 1 の連続が多い雑音が現れる。

以上のように, 人工物からの磁気雑音は, 1 が孤立したパ ルス性または 1 が連続したバースト性のものが多い.人間環 境との接触による生態の変化や病気感染も動物生態学の研究 対象なので, 人工物の混在する環境も想定し, 符号系にはこ れらの雑音の対策も含めるべきである.

第 2 章の議論から, 符号集合には次の性質が必要である.

(1) 符号間のハミング距離が離れている.

（2） 1 のビット数が極めて少ないものは含まない.

(3) 符号密度が低い.

また, 人工物からの雑音対策のため, 次のものが加わる.

(4) 孤立パルスを誤認しにくい.

(5) バースト雑音を誤認しにくい.

このうち（4）は（2）と両立するが, さらに0のランレン グスが長すぎるものは符号集合から除外した。一方（5）は， 0 が挟まることもあり, 決定的な識別は難しい.しかし 1 の ランレングスが極端に長い場合が多いことは確かであり，こ のようなものは符号集合に含めない

実際には，距離 3 のハミング符号系の中で， 1 ビットずら したものとの排他的論理和が 1 を 10 個以上含むものだけを 符号集合の要素とした。これにより（2）（4）（5）を同時に 満足させ，かつ正しい符号かどうかの判別も容易になる。こ のようにして，探索によって 622 個からなる 14 ビット符号 の集合を得た。この数は, 必要な標識の個数に対して十分で ある．符号密度は平均 $622 / 214=0.038$ である。

\section{4. 実用回路の設計}

磁場があれば 1 を検出し，0，1のパターンを符号として認 識するものを，センサ系と呼ぶ．実際に観測を行うには，動 物個体にはセンサ系, 電池, メモリや管理用の CPUなどを 含むユニットを首輪などの形で取り付ける．以後このユニッ ト全体を行動記録装置と呼ぶ.

[要求性能] 動物生態学用の目的では, 精度要求や制約 条件は工業計測での常識とはかなり異なる。検出域半径は 3〜 $4 \mathrm{~m}$ と大ざっはで, 要求精度は低い. しかも変動に対する 
理論的な堅牢さは前章ですでに確保されていて, 精度要求を 満足するのは容易である。しかし行動記録装置全体で $150 \mathrm{~g}$ 以下の重量, 3 ケ月の電池寿命が要求される.

標識も, 山野に設置するため電池駆動する，消費電流を抑 え，電池交換の人手を省きたい. 1 回の観測に 100 個程度必 要とするため, 簡便で低コストが要求される.

[周波数］低周波の交流磁場を用いる。いうまでもなく 磁気センサが単なるコイルですみ，増幅も容易だからである． 周波数が低いとセンサコイルのインダクタンス, 共振容量と も大きく，重くなる。一方増幅器の回路インピーダンスを上 げて電源電流を抑えると，浮遊容量などにより周波数特性が 制限される．筆者らの用いた回路技術では， $5 \sim 20 \mathrm{kHz}$ がト レードオフ範囲であった。符号レートは $0.25 \mathrm{bit} / \mathrm{ms}$ なので, キャリア周波数として低すぎることはない.

低周波では検出域は波長に比べて極端に小さく，自由空間 での磁場の形は直流と変わらない，導体があると交流磁場 は渦電流を生じ, 周波数が高いほど遮蔽を受ける。しかし $10 \mathrm{kHz}$ 程度では，コイルに金属板を近接させないかぎり，水 道水や湿った土壤程度では影響はみられず，標識を地表に直 接設置しても，観測対象が巣穴に入っても支障はない。なお 高透磁率材料の影響は直流磁場と同様に受けるが，実験的に は鉄筋ビル内でも検出域が若干拡大する程度であり，また山 野に大量の磁性材料があることは考えにくい.

民家の付近では TV 受像器の偏向コイルの開放磁路は $15.734 \mathrm{kHz}$ の外乱源になり得る。 $10 \mathrm{kHz}$ 以上には無線航行 局がある。これらを避け，筆者らは任意に $8 \mathrm{kHz}$ とした。

[標識］標識の磁場を強くしセンサ感度を下げれば, S/N 比は上がるが，消費電力は抑制したい．磁場生成用コイルを 共振させれば, 駆動電流に対し励磁電流を非常に大きくで きるが，Q 值が高すぎればシリアル符号にも追いつかない. 筆者らは, 直径約 $9.5 \mathrm{~mm}$, 長さ $120 \mathrm{~mm}$ の棒状フェライト コアに $0.7 \mathrm{EC}$ を巻いた $396 \mu \mathrm{H}$ のコイルを, $1 \mu \mathrm{F}$ のフィル ムコンデンサと並列共振させ, CMOS IC の 4050 を 3 ゲー トずつ並列にして，両端逆相の $8 \mathrm{kHz}$ の矩形波で駆動した. 電源電圧は $9 \mathrm{~V}$ とした。コイルの端子間電圧はほほ正弦波で $20 \mathrm{Vp}-\mathrm{p}$ ，すなわち共振電流は $1.0 \mathrm{Ap}-\mathrm{p}$ である。包絡線の応 答は，実測で立ち上がり約 $350 \mu \mathrm{s}$ ，立ち下がり約 $150 \mu \mathrm{s}$ であ る. 励磁時の電源電流は実測で約 $25 \mathrm{~mA}$, 符号ビットを全部 1 ，送信のデューティ比を $1 / 4$ と仮定すると， 800 時間（約 1.1 ケ月) で単 1 型マンガン乾電池の常識的な電流容量 $5 \mathrm{Ah}$ に達する、コア先端部での磁束密度は, 実測約 $3 \mathrm{mT}$ であり, 安全上の問題はないと考える。たとえば黒板用マグネットは 50〜150mTである.

[センサ系の構成］ センサ系は, 磁気センサの後に, 初 段増幅器, $\mathrm{AGC}$ 増幅器およびアクテイブフィル夕, 整流平滑 器, 比較器, 符号解読器を縦続接続して構成する。比較器か ら 0,1 を得る。符号解読器はソフトウェアであり, 行動記 録装置の管理用 CPU を利用して実現する．筆者らは初段増 幅器から比較器までを 11 個のディスクリートのバイポーラ

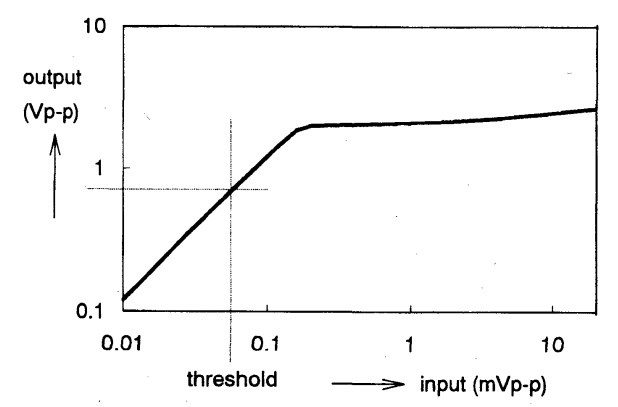

Fig. 3 Input-output characteristics of AGC amplifier.

トランジスタで構成し, 電源電圧 $5 \mathrm{~V}$, 消費電流約 $200 \mu \mathrm{A}$ で 動作させている．3ケ月で $430 \mathrm{mAh}$ になり，2 本直列にした リチウム電池 CR123A の容量の $1 / 3$ に相当する.

[センサ] 磁気センサ用コイルは, 直径 $8 \mathrm{~mm}$, 高さ $10 \mathrm{~mm}$ のドラムコアに巻かれた市販の $30 \mathrm{mH}$ のインダクタ を利用し， $0.0132 \mu \mathrm{F}$ のフィルムコンデンサと並列共振させ た. 半值帯域は, $7.2 \sim 8.7 \mathrm{kHz}$ である。標識から距離 $1 \mathrm{~m}$ に おいて出力 $3.67 \mathrm{mVp}-\mathrm{p}$ であった. 包絡線の時定数は約 $400 \mu \mathrm{s}$ である. 共振点は停留点なので, 素子定数の変化と利得変 化は線形ではない．5\%の増加，減少によりそれぞれ約 $11 \%$, $7 \%$ 利得低下し，10\%の変動に対しては約 $25 \%$ でる。その ため共振の初期調整は必要である。温度係数はコンデンサは 大きくても $5 \times 10^{-4} /{ }^{\circ} \mathrm{C}$ 程度である. インダク夕は不明であ るが, 実測では, $+40^{\circ} \mathrm{C} \sim 0^{\circ} \mathrm{C}$ に対する利得低下は $2 \%$ 以下 であった。これによる検出域半径の変化は $0.7 \%$ である。ま た比較器の閾値の温度変化により, $\pm 30^{\circ} \mathrm{C}$ 対して検出域半 径は土3\%変化する。

[AGC］AGC，すなわち自動利得調整は，双極子磁 場の逆 3 乗則に基づく検出域境界の堅牢さを補完する．対象 が標識に接近すると，センサ出力は逆 3 乗則によって非常に 大きくなり, 先行する 1 の部分から 0 の部分に侵入した減衰 波形も，検出域境界付近での 1 に対する出力をはるかに超 える。このときでも 0,1 を判別し符号受信を正常に行うに は, AGCによって増幅器の利得を下げるしかない. 筆者ら の AGC 回路は, バイポーラトランジス夕を可変抵抗素子と した. Fig. 3 には, 初段増幅器から AGC 増幅器を通り,ア クティブフィルタまでの特性の実測結果を示す. 比較器によ る 0,1 判別の閾值は入力換算で $58 \mu \mathrm{Vp}-\mathrm{p}$ で, この約 2.5 倍 の入力電圧から出力が増加しなくなる. 入力 $10 \mathrm{mV}$ 以上では 増幅器のリミッ夕特性が出力を制限する.

[検出域の変動] この初段増幅器から比較器 までを上記のセンサと組み合わせた場合, $r_{0}$ の値は $1 \mathrm{~m} \times(3.67 \mathrm{mV} / 58 \mu \mathrm{V})^{1 / 3}=$ 約 $4 \mathrm{~m}$ である. 第 2 章に示し たセンサの高さと傾きによる検出域半径の変動を 0 〜 - $6.5 \%$, Fig. 2(b) による検出域の変化を $-0.8 \sim-2.5 \%$, 温度変化に 伴う共振点および間值のずれを+3〜 - 5\%と見積もれば, $r_{0}=4 \mathrm{~m}$ に対して検出域半径の変動範囲 $4.1 \sim 3.4 \mathrm{~m}$ を得 る. $3 \sim 4 \mathrm{~m}$ の要求に対してはまだ $13 \%$ の余裕があり,これを 


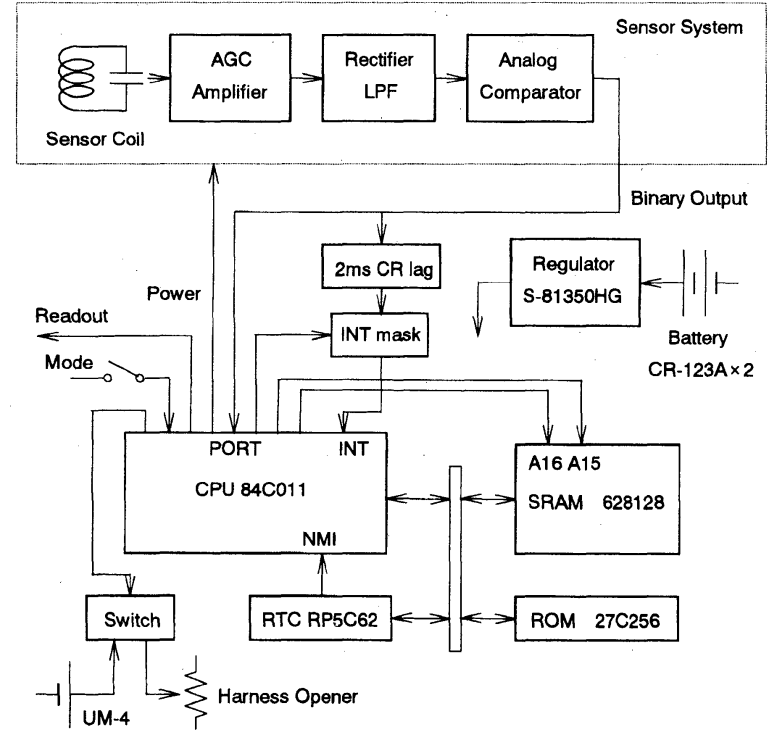

Fig. 4 Schematic diagram of an instrument which records trace of wild animal.

標識の電池電圧に振り向ければ, 放電終止電圧を $6.5 \mathrm{~V}$ とす ることができる。

[不規則雑音］ センサを短絡した状態で，入力換算で約 $3 \mu \mathrm{Vr}$.m.s., $20 \mu \mathrm{Vp}-\mathrm{p}$ 程度の定常的なノイズがみられ, 内部 雑音と推測される.この雑音が整流, 平滑され, 比較器の入 力では, 約 $8 \mathrm{mVr} . \mathrm{m} . \mathrm{s}$, ピークで約 $25 \mathrm{mV}$ の低域通過型のガ ウス性と見なせる不規則雑音となる。コイルの短絡を解除す ると, 比較器の入力位置での雑音は $20 \mathrm{mVr} . \mathrm{m} . \mathrm{s}$ 程度になる. 実験室内環境では内部雑音と同程度の定常不規則な外部雑音 があるものと思われる。このとき, 䦨値の実測值 $550 \mathrm{mV} に$ 対して,$n / \theta \simeq 0.036$ である.

\section{5. 小動物の行動記録システム}

本論文の存在検出系は, 小動物の行動記録システム (trace re corder）に用いる.このシステムでは, 定点に標識（beacon） を設置し, 観測対象の動物個体には, Fig. 4 のような, セン サ系, 時計 (real-time clock,RTC), 大容量 SRAM (static RAM) チップを含む行動記録装置（recordingunit, RU) を 装着する。行動記録装置はマイクロ CPUによって管理され ている。この CPUはセンサ系の一部である符号識別を兼ね, 標識の識別子を時刻とともに大容量 SRAM に時系列記録す る. 観測期間終了後この行動記録装置を回収し,ケースを壊 して SRAM から記録を読み出して解析する。

実際に使用した CPU，TMPZ84C011 は 4MHz 動作時約 $15 \mathrm{~mA}$ 要するが, 命令によりクロックを停止し, 500nA 以 下のスタンバイ状態となる。割込み，ノンマスカブル割込 み (non-maskable interrupt, NMI) により, CPUは214ク ロック待ち発振を安定させてから実行再開する。またクロッ クを停止させないアイドル状態では, 約 $1.5 \mathrm{~mA}$ 消費する。こ れらの機能を利用して CPUの電流消費を極度に抑えるアル

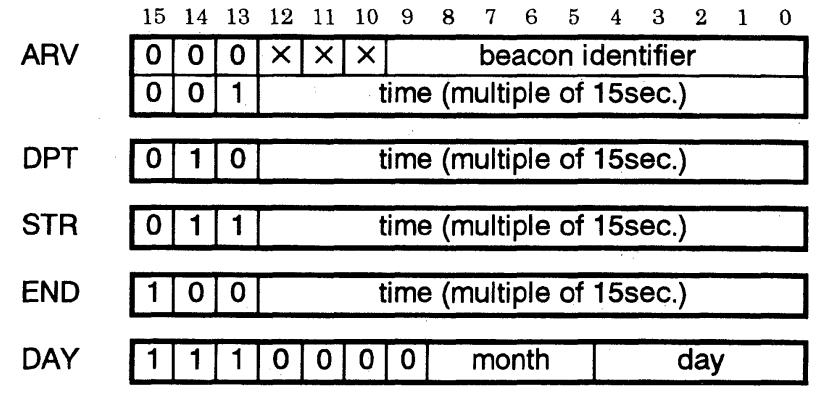

Fig. 5 Data types in the trace-recording instrument.

ゴリズムを考案し， ROM 内のプログラムに用いた。

比較器の出力が 0 のままのとき, CPUはスタンバイ状態 にあり，ほとんど電流を消費しない．比較器の出力が 1 にな ると，これをスタートビットとし，CR 回路による $2 \mathrm{~ms}$ の遅 延の後, 割込が要求される. 214 クロック待ちの後, 割り込 み処理プログラムの中で，符号の第 1 ビット（LSB）のほほ 中央が来るべき時刻から，ソフトウェアで調歩同期して比較 器の出力時系列がポートから読み取られる。このとき $4 \mathrm{~ms} の$ 待ち時間を得るにも RTC の定周期割り込みを利用し，大部 分の時間 CPUをアイドル状態において電流量を減らす。符 号検出一回当たりの電流量は的 $200 \mathrm{nAh}$ である.

動物が標識の付近に留まるとき符号検出が何度も繰り返さ れ, その度毎に電流を消耗するのを防ぐため, 符号受信に成 功すると, 記録分解能に等しい 15 秒間, センサ系の電源を オフにして不応期に入る。この期間の全消費電流は約 $20 \mu \mathrm{A}$ である，RTCによるNMI で不応期を脱する。

記録するデー夕は，標識の識別子と符号が検出され始めた 時刻 (ARV)，検出されなくなった時刻 (DPT) である. 識 別子は符号のビットパターン自体ではなく, 通し番号である. 時刻の分解能は 15 秒とした。符号受信期間がこれより短い 場合は, DPTを省略する. 日付の变わったときに特定のワー ド (DAY) を挿入する。これらのデー夕は, Fig. 5 に示す ように，ワード境界に一致する可变長で，時系列順に格納さ れる。デー夕列の一部からでも，その中にDAYを含めば, デー夕は確定して読みとれ, 万一のポインタの破壞等によっ て失われない。また CPU のプログラムもスタックポインタ を常時再初期化する構造とし，CPUが未知の原因で暴走し ても，センサ系からの割り込みをきっかけに自己復帰する.

行動記録装置は防水, 耐磨ケースに電池とともに封入して しまうと, 外部とのインタラクションは磁場による符号と, ケースを透ける LED の応答しかない. そのためいくつかの 符号を，利用者とのインタフェース用に配分する。利用者は 放獣前に記録開始指令の符号を送る。また観測期間の終了時, 動物が立ち寄る可能性の高い場所の標識を動作停止指令の 符号を出すものに置き換える，前者を検出した以後 CPUは SRAM への記録を開始し, 後者を検出するとセンサ系の電 源を切る. 割り込み要因を失うため, 以後 CPUは再起動し 
ない。これらを検出したことは, STR ワード, END ワード として SRAM の記録中に残る。行動記録装置の回収は再捕 獲による、アナグマは再捕獲が容易であるが夕ヌキは学習能 力が高く再捕獲しにくい.この対策として, 動作停止指令を 検出した際同時に動作させる，行動記録装置を自動的に離脱 させる機構も試作したが, 詳細は省略する.

輸送時の自動車のイグニションノイズはあらゆる符号と誤 認され得る. 対策以前, 動作停止指令符号と誤認された例も あった. 自動車による搬送中には, 特定の指令符号を出すダ ミーの標識をごく接近させておき, 行動記録装置はこの符号 を検出すると約 10 分間観測を休止する．また未知の雑音に より符号集合に含まれないビットパターンが多く現れたとき， 約 1 分間不応状態にして電流の浪費を抑制する。

行動記録装置は電池を含めて幅 $75 \mathrm{~mm}$, 高さ $40 \mathrm{~mm}$, 厚さ $25 \mathrm{~mm}$ の直方体の上部を動物の首に合わせて円弧状に $15 \mathrm{~mm}$ 切り下げた形のケース内に収納され，2 本直列にしたリチウ ム電池 CR123A で約 3ケ月間動作する．首輪によって動物に 取り付けたときセンサコイルの軸はほぼ鉛直になる。重量は 外装を含めて $130 \mathrm{~g}$ である. 標識は, 公称 $75 \mathrm{~mm}$ の塩化ビニ ル製水道管を利用した最大部直径約 $90 \mathrm{~mm}$, 長さ約 $250 \mathrm{~mm}$ の防水ケースに, 単 1 型乾電池 6 本とともにコイルを長手方 向に向けて封入し, 地表に縦向きに設置する. 平地でのコイ ルの高さは，センサコイルにほぼ等しくなる。

\section{6. 存在検出系の動作試験}

センサや増幅器など, センサ系各構成要素単体の動作試験 については, 第 4 章に論じたので, ここでは存在検出系とし ての試験結果を示す. 前述のように符号の判定は行動記録装 置側の CPU を利用しているので, 実際に試験に用いるのは 行動記録装置全体である。この組み込みプログラムを，すべ ての検出事象を棄却せず記憶し, かつ観測休止を行わないよ うに変更して動作試験を行った。調歩同期によるシリアル符 号の復号の性質上, 全ビットパ夕ーンのうち 1 ビットでも 1 となり, かつスタートビット，ストップビットの一方でも 0 となれば，ストップピットなしと判断される。

Fig. 6 に行動記録装置を標識からの距離を $5 \mathrm{~mm} / \mathrm{s}$ の割合 で近づけていったときの, 検出域境界を通過する前後の検出 記録例を時系列上に示す。測定を行った場所は, 建物に近接 した屋外, 用いた標識の符号のビットパターンは 16 進表記 で 3DA4で， 1 を 8 個含む. 最上段は正常検出，第 2 段は符 号の誤認, 第 3 段は符号集合に含まれないビットパターン, 第 4 段はストップビットが見つからなかったもの，第 5 段は 全ビット 0 だったものである. 存在検出系では, 第 3 段以下 は存在検出なしと判断される.

正常検出は, 約 $55 \mathrm{~mm}$ の間に $0 \%$ から $100 \%$ に推移する結 果を得た. Fig. 2(a)を 1 の数 8 ビットに改めたものの $p_{0} に$ に, センサ系が静止しているときのスタートビット，ストップビッ トの検出確率を乗じたものと, 得られた正常検出結果を視認 比較すると，ほほ同じ距離で同等の推移をしているのがわか

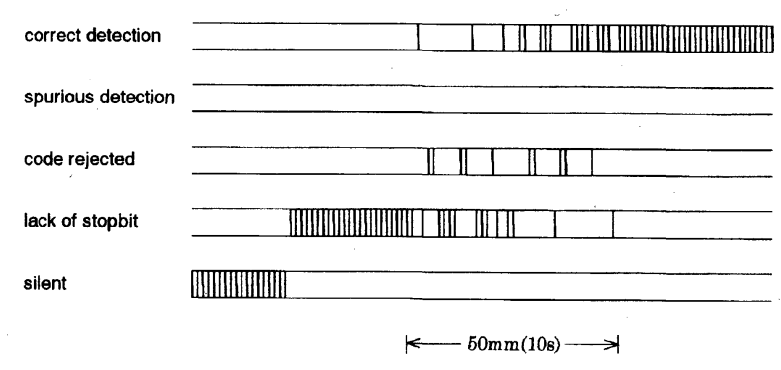

Fig. 6 Experimental result showing code discrimination near the boundary of detectable area.

る.ただし $n / \theta$ は，第 4 章による定常不規則雑音の直接観測 值 0.036 を用いた。符号集合に含まれないビットパターンは 10 回出現したが, 誤認はまったくなかった. 実際の存在検出 系は，ほぼ第 2 章のモデルどおりに動作している。

\section{7. 使用結果}

本存在検出系は, これまで電波テレメトリでは不可能で あった空間分解能と時間的観測密度で, 野生小動物の行動を 観測する手法として提案したものであり, 競合する方法がな いことは，第 1 章に述べたとおりである. しかしこの系が案 のとおり実用的であるためには, 実際の動物生態学者の研究 用に良好なデー夕を供給できることが示されなければなら ない.

実際の野生動物に対し，この存在検出系による行動記録シ ステムを用いた実験を 3 回行った。第 1 回目は 1996 年 11 月 16 日から 12 月 10 日にわたって, 東京都日の出町において標 識 24 個を敷設し，メスのタヌキ 1 頭に対して実施した7),8). 標識は目標のごく近くの地表面に, 立木などを利用して固定 する，行動記録装置とともに，電波テレメトリ用の発信器も 同じ首輪に取り付けた。両者の相互干涉はない。この実験は, 装置の動作を確認し, 不適切な点を抽出することを目的とし た予備実験である，標識数が少なかったうえ，行動圈が放獣 後少し移動してしまったことにより, 観測期間中得られた記 録は 99 個で，この間の行動全体を再現するのに十分な記録 密度は得られなかった。また符号系が 3 章に示したものを考 案する以前のものであったため, 誤符号の記録が多く手作業 で除去する必要があった．スタンバイ時間の設定を 3 分とし ていて長すぎたため, 来てすぐ立ち去ったと思われる夕メフ ンの滞在時間が得られなかった. しかしそれでも, 農家が野 積みにしているゴミ捨て場への高い依存性, タメフンによる 情報交換などを示す行動記録が得られ，実際の研究に応用し た場合, 有用なデー夕を得る可能性を伺わせた。この程度の 観測結果でも, 電波テレメトリによって得るのは困難である。

第 2 回目の実験は, 1997 年 4 月 15 日から 6 月 7 日まで, 東京都日の出町に観測エリアを設定し，65 個の標識を敷設 し, 実際にアナグマの研究用デー夕を得る目的で実施した。 対象としたのはオスの 3 才の個体である. 途中一度再捕獲さ れ, 記録を回収後, 行動記録装置を交換して再度放獣した。 
第 3 回目は 7 月 5 日から 8 月 20 日まで，第 2 回目のときの ものを含む 3 頭のアナグマを対象として行った研究目的のも のである. 以下，第 2 回目の実験の 2 度目の放獣後の連続的 な記録に基づいて論ずる。

行動記録装置に記録開始指令を入れたのは 4 月 26 日である が, 放獣は 4 月 29 日である. 再捕獲して行動記録装置を実験 室に運んだ後，6月 10 日に動作停止指令を送った.STRTか ら END までの間に 577 個の記録がある.このうち STRT か ら放獣までと ENDの直前に，それぞれ輸送中のイグニショ ンノイズを誤認したと思われる記録が 4 個ある。これらは， 標識識別子が使用した 65 個に含まれないこと, 実験者が行 動記録装置の履歴を承知していることによって，容易に区別 できる．記録の内容から，再捕獲の罠にかかったのは 6 月 7 日午前 3 時 20 分頃である．以後，同じ標識の記録が 47 個連 続している，放獣から罠にかかるまでの間の記録は, 521 個 である。この間，使用した 65 個に含まれない標識識別子や動 物の移動速度から考えて不自然なものなど，符号の誤認によ ると思われる記録はまったく存在しない，存在検出による方 式では, 対象が検出域の境界を出入りするような形で徘䧃す ると，同じ標識識別子の時刻の接近した記録が数個連続する. 記録の中にも，そのような箇所が巣穴の入口やゴミ捨て場な どの特定の場所の標識について見られる。このような検出域 境界横断の機会の多い部分にも, 異常な記録は存在しない.

もちろん不自然に見えないような誤認の可能性は，完全に は否定できない。しかしそれが起こり得るのは，622 個の符 号中せいぜい 10 個程度のものに誤認されたときであり，不自 然な誤認に比べてはるかに起こりにくい. 不自然な誤認によ る記録がまったくない以上，自然に見える誤認による記録が 存在するとは考えにくい. 実用環境においても，この存在検 出系は第 2 章に予測したとおり, 動物生態学者に誤ったデー 夕を供給する盧は非常に小さいと言える.

得られた記録の一部を Table 1 に示す。記録の正しさの 次に, 得られる情報の量について論ずる。これは, 動物生態 学者による行動圏の事前調査と, 標識数および設置個所の適 切さに依存する。本実験では，期間中 1 度以上記録のある標 識は， 65 個中 43 個で， $2 / 3$ に達する．また検出域の面積の 総和は，観測エリアの $0.15 \%$ にずないが, 記録された時間 の総和は観測期間の $6 \%$ あるる。れは, 多くの記録を得る のに適切な標識設置場所が, 実際に設定可能であることを示 している

1 日当たりの記録個数は，単純平均で 13 個である. しかし 記録個数は毎夜（アナグマは夜行性）一様ではなく，数個か ら 20 数個と大きくばらつく. 期間中 3 日だけ昼行性の記録 もあり，5月 17 日，6月 5 日の 2 夜だけは記録がまったくな い. 標識の敷設してある観測エリアの外に出たと思われる. また記録の少ない夜も，経路と時間経過から観測エリア外に 行ったと推定される記録がいくつかある.すなわち標識数 65 個では，行動を完全に捕捉できる観測エリアを設定するには 不足であり，この $2 \sim 3$ 倍， 150～200 個が必要であると考え
Table 1 Records of wild male badger's two ordinary nights in late spring.

\begin{tabular}{|c|c|}
\hline ID & ARV m-d h:m:s DPT m-d h:m:s \\
\hline [ 23] & $5-3019: 13: 45-5-3019: 13: 45$ \\
\hline [ 26] & $5-3019: 15: 45-5-3019: 15: 45$ \\
\hline 5] & $5-30$ 19:18:15 - 5-30 19:18:15 \\
\hline [ 15] & 5-30 19:24:00 - 5-30 20:18:30 \\
\hline [ 15] & $5-3020: 22: 45-5-3020: 27: 30$ \\
\hline [ 15] & 5-30 22:07:30 - 5-30 22:35:00 \\
\hline [ 15] & $5-3022: 37: 00-5-3022: 37: 15$ \\
\hline [ 11] & $5-3022: 39: 45-5-3022: 40: 15$ \\
\hline 9] & $5-3023: 10: 00-5-30$ 23:13:15 \\
\hline 9] & $5-3023: 36: 30-5-3023: 58: 30$ \\
\hline 9] & $5-3023: 59: 30-5-3100: 00: 30$ \\
\hline [ 15] & $5-3100: 32: 30-5-3101: 08: 30$ \\
\hline [ 15] & $5-3101: 56: 15-5-3102: 28: 15$ \\
\hline [ 15] & $5-31 \quad 02: 49: 30-5-3102: 50: 00$ \\
\hline [ 15] & $5-3102: 59: 30-5-3102: 59: 30$ \\
\hline [ 34] & $5-31$ 03:04:30-5-31 03:09:15 \\
\hline [ 37] & 5-31 03:45:30-5-31 03:46:30 \\
\hline
\end{tabular}

ID ARV m-d h:m:s DPT m-d h:m:s

[ 40] 5-31 18:57:15 - 5-31 18:57:30

[ 53] 5-31 19:07:00-5-31 19:07:30

[ 54] 5-31 19:09:30 - 5-31 19:09:30

[ 21] 5-31 19:19:30 - 5-31 19:19:30

[ 13] 5-31 21:28:15 - 5-31 21:28:15

[ 11] 5-31 21:33:30-5-31 21:33:30

[ 15] 5-31 21:35:45-5-31 21:42:30

[ 15] 5-31 21:43:30 - 5-31 22:01:45

[ 15] 5-31 22:03:15 - 5-31 22:06:00

[ 15] 5-31 22:07:15 - 5-31 22:56:45

[ 15] 6- 1 01:50:30-6- $101: 56: 30$

[ 15] 6- 1 02:01:15-6- 1 02:03:45

[ 15] 6- $102: 17: 30-6-102: 17: 45$

[ 15] 6- $102: 23: 00-6-1$ 02:23:15

[ 22] 6- $103: 07: 00-6-1$ 03:07:00

[ 16] 6- 1 04:14:00-6- $104: 14: 0$

[ 27] 6- $104: 16: 15-6-104: 16: 30$

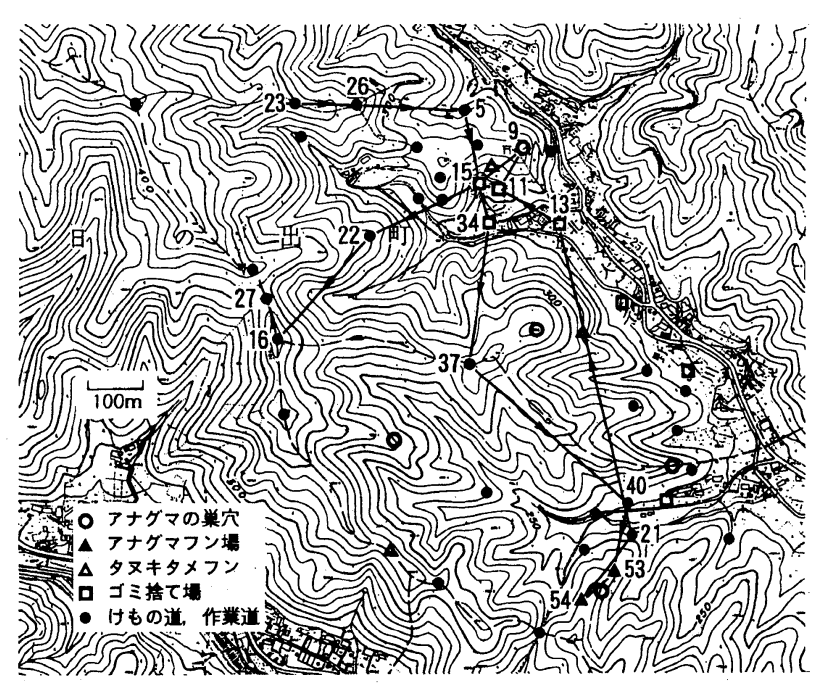

Fig. 7 Trace of a badger in Table 1 plotted on a map of beacon distribution.

る. 符号数と同じ約 600 個あれば申し分ない.

Fig. 7 には, Table 1 に対応する部分の行動を地図上に示 す。しかし各夜の行動を逐一再現しても一般的な知見にはな らないので, 次に著者らの中の動物生態学の研究者による行 動パターンの解析結果を略述する.

対象個体の一夜の行動パターンは 9 種類あり, 大別して巣 穴滞在型, 慨づけ場と周辺の徘䧃型, 餌づけ場と行動圈内の 巣穴やフン場のチェック型, 行動圏外の巣穴やフン場のチェッ ク型に分かれることが示された。これらの行動パターンを 3〜4 日の周期性で使い分けている. チェック行動が多いのは, 交尾期のオスであるためと考えられる。第 3 回実験における 同一個体の 7 月 10 日〜8月 12 日の記録からは，夏期にはほ とんどが飭場と巣穴の周辺の滞在のパターンになることも示 された．解析の詳細は動物生態学分野への報告に譲り ${ }^{9)}$, こ こでは，得られた記録が行動パターンを抽出するのに十分な 情報をもっていることの例証とするにとどめる.

また記録からは，畑の隅のゴミ捨て場へは（飭として利用 
するため) よく訪れ，蓋のあるコンポスト容器にも来るが, 柵で囲ったコンポス卜容器には来ないというような, 目的を 絞った観測結果も抽出できる。「来ない」と言えるのは, 来れ ば必ず記録する行動記録装置によっているからである。

以上, 動物生態学の研究への使用結果から, 磁気符号によ る存在検出系を用いた行動記録システムは, 動物生態学者に 正確で有効な小動物の行動記録を供給できる能力があること が示された. 実際に有効な情報を得るには, 動物生態学者側 による観測の企画と標識配置の設定が重要である.

\section{8. 結言}

磁気双極子による磁場のオンオフによるシリアル符号によ り, 極めて単純でかつ理想に近い特性をもつ存在検出系を構 成できることを, 場の形および符号検出のモデルによって論 じ,これに基づく検出系の実現例を示した。この実現例は野 生小動物の行動記録に用いるものであり, そのための行動記 録システムおよび行動記録装置についても論じ, 実際にアナ グマの生態観測に適用した結果，有用性が示された。

さらに詳しい行動記録を得るため,「横断検出系」を併用 するアイデアもある，標識の双極子コイルを，例えばTVの $300 \Omega$ フィーダのような少し間隔のある平行線 $100 \mathrm{~m}$ 程度の 先端を短絡して細長いワンターンコイルとしたものに惪き換 えることによって実現可能である.

\section{謝 辞}

快く飼育個体による装置試験の場をご提供いただいた早稲 田大学人間科学部自然環境調査室大堀聰調查主任および研究 室の皆様，野生個体の捕獲等試用実験に際してご尽力いたた いた東京野生生物研究所神田栄次氏に感謝の意を表する。本 研究の一部は, とうきゅう環境浄化財団の補助によるもので ある。

$$
\text { 参 考 文 献 }
$$

1) Mech L. D.: "Handbook of Animal Radio-Tracking", University of Minnesota Press (1993)

2) Cochran W. W.: "Wildlife Telemetry", Wildlife Management Techniques Manual, 4th ed.(edited. by Schemnitz S.D.), 507/520, The wildlife society, Washington D.C. (1980)

3）“RF-ID SYSTEM", 日製産業株式会社, 03-3504-5139 (1998)

4) Adams L., and S. D. Davis: "The Internal Anatomy of Home Range", J.Mamm., 48., 529/536 (1967)

5) Lars Edenius: "Field test of a GPS location system for moose Alces alces under Scandinavian boreal conditions", Wildlife biology, 3, 1, 39/43 (1997)

6) 阿刀田, 中村, 富澤, 横山, 今田: “磁気式モーションキャプ チャ装置における双極子配置と座標逆算アルゴリズムの一設計 法”, 計測自動制御学会論文集, Vol.34, No.5, 445/453 (1998)

7) Y. Kaneko, T. Suzuki, N. Maruyama, O. Atoda, N Kanzaki, and M. Tomisawa: "A Trace Recorder and Its Use for tracking a Raccoon dog", Trans. 23rd IUGB Congress, Ryon, France, 1/6 (1997)

8) Y. Kaneko, T. Suzuki, N. Maruyama, O. Atoda, N Kanzaki, and M. Tomisawa: "A New Device for Trace Recorder and Its Use of a Home Range Survey for a Raccoon Dog",
J. Mamm.Soc Japan, submitted.

9）金子, 鈴木, 丸山, 阿刀田, 神崎, 冨澤: “新テレメトリーシ ステム「トレースレコーダー」のアナグマの環境選択調査へ の応用”, 第 3 回野生生物保護学会大会要旨, 43 (1997)

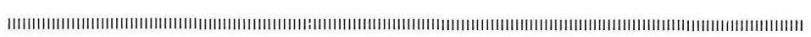

$$
\text { [著者 紹 介] }
$$

鈴木岳良

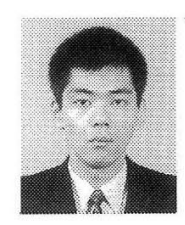

1996 年農工大·工・電子情報卒. 1998 年東京 農工大学大学院生物システム応用科学研究科博士 前期課程修了. 現在, 横河電機 (株).

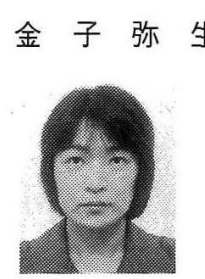

1989 年麻布大 ・ 獣医卒. 1992 年東京農工大学 大学院農学研究科修士課程了. 1998 年同連合農学 研究科修了. 現在財団法人卜ヨ夕財団研究員: 二 ホンアナグマの環境選択, 中型哺乳類に対する住 民意識等研究.

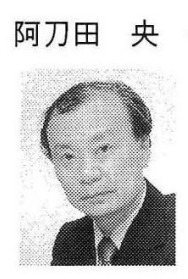

- (正会員)

1970 年東大.工. 計数卒. 1975 年同大学院博 士課程了. 同大 · 工 助手, 講師を経て, 1978 年 農工大.工・助教授. 1990 年同教授. 1995 年東 京農工大学大学院生物システム応用科学研究科教 授. 工博.

\section{丸山直 樹}

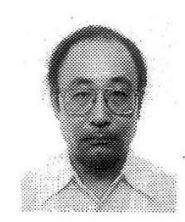

1966 年農工大 ·農 · 林学卒. 新潟県林業試験所 技師. 1968 年農工大 · 農 - 助手. 1987 年同助教 授. 1997 年同教授。農博.

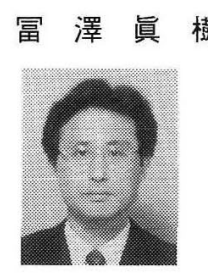

1987 年東京農工大·工·数理情報卒. 1992 年同 大学大学院博士課程了. 1992 年東京農工大.工. 電子情報工学科助手. 1997 年前橋工科大学工学 部情報工学科講師. 工博.

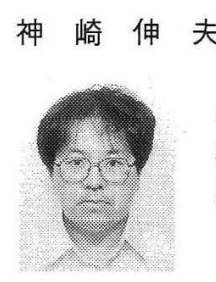

1995 年筑波大 $\cdot$ 生物学類卒. 1988 年農工大大 学院農学研究科修士課程了. 1991 年同連合農学 研究科了. 農工大 · 農 ·助手. 1998 年同助教授. 農博.

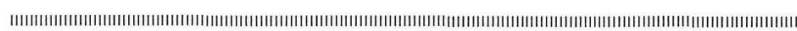

